\title{
A Map of Things Known and Lost in Anne Enright's The Green Road ${ }^{1}$
}

\author{
Margarita Estévez-Saá \\ University of Santiago de Compostela, Spain
}

Copyright (c) 2016 by Margarita Estévez-Saá. This text may be archived and redistributed both in electronic form and in hard copy, provided that the author and journal are properly cited and no fee is charged for access.

\begin{abstract}
The present contribution interprets Anne Enright's most recent novel, The Green Road (2015), as the story of two decades of an Irish family that is used by the writer to offer an alternative fictional rendering of the history of Ireland and the Irish from the 1980s till the early twenty-first century, as well as, formally speaking, a further contribution to the Irish writers' penchant for destabilizing the conventions of a literary genre too frequently associated with British settlement and stability (Eagleton 1995) and with nineteenth-century realism (Hand 2011); and, therefore, recurrently considered as unable to apprehend the disruptive and multifaceted condition of Ireland and the Irish. Enright goes from the particular to the universal: the story of the Madigans serves to cover the recent history of Ireland as well as to deal with concerns such as motherhood, religion, sex, aging depression, illness, materialism and migrations, among others. Formally speaking, Enright's latest novel is undoubtedly the most daring and innovative text in her already vast literary output and can and should be interpreted as the author's most remarkable contribution to a literary genre with which Irish writers have not ceased to experiment.
\end{abstract}

Key Words. Anne Enright, The Green Road, Family, Contemporary society, Irish history, Irish novels.

Resumen. La presente contribución interpreta la novela de Anne Enright, The Green Road (2015), como el relato de una familia irlandesa, que a su vez ofrece un versión alternativa de la historia de Irlanda y de los irlandeses desde los años 80 hasta principios del siglo XXI, así como, en términos formales, una muestra más de cómo los escritores irlandeses desestabilizan las convenciones de un género literario tradicionalmente asociado con la estabilidad británica (Eagleton 1995), y el realismo literario del siglo XIX (Hand 2011); y, en consecuencia, recurrentemente considerado como incapaz de aprehender la compleja e inestable condición de Irlanda. Enright va de lo particular a lo universal: el relato de la familia Madigan sirve a la autora para cubrir la historia reciente de Irlanda así como para tratar temas relevantes en la sociedad contemporánea como la maternidad, la religión, el sexo, la vejez, la depresión, la enfermedad, el materialismo, o las migraciones. La última novela de la escritora es, sin duda, el texto más osado e innovador en su ya dilatada trayectoria literaria, y debe ser interpretado como su contribución más destacada a un género literario con el que los escritores irlandeses no han cesado de experimentar.

Palabras clave. Anne Enright, The Green Road, familia, sociedad contemporánea, historia de Irlanda, novela irlandesa.

1. This essay is part of a wider research funded by the Spanish Ministerio de Economía y Competitividad (FEM2015-66937-P).

ISSN 1699-311X 
There is an ongoing debate among critics of contemporary Irish literature that divides those specialists who consider that Irish writers are too intent on revisiting the past history of the island, from the, comparatively speaking, scarce number of scholars who have been able to notice how contemporary Irish authors are minutely dissecting in their fictions the present socio-cultural circumstances of Ireland. Therefore, Fintan O'Toole (2001, 2010), Declan Kiberd (2005), Julian Gough (2010), and Eamon Maher and Eugene O'Brien (2014) represent those critical voices that maintain that the Irish writers are too intent on, almost obsessed with, looking to the past, and that they seem unable to dissect in their fictions the changing atmosphere of the island. Thus, Julian Gough stated in 2010 that "If there is a movement in Ireland, it is backwards. Novel after novel set in the nineteen seventies, sixties, fifties. Reading award winning Irish literary fiction, you wouldn't know television had been invented" (1). More recently, Eamon Maher and Eugene O'Brien exemplified this alleged disregard for the present focusing on the years of prosperity in Ireland, and wondered why "it was that our writers and artists, along with politicians, economists, academics and the media in general, failed to alert the public in an adequate manner to the dangers associated with the Celtic Tiger. Why was there no major novel, for example, that exposed what was really happening in Ireland at that time?" (2014: 6).

Nevertheless, Anne Fogarty (2003), Eilís Ní Dhuibhne (2010), and Susan Cahill (2012) have been able to identify authors and works concerned with bearing witness to contemporary life in Ireland. In this sense, Ní Dhuibhne proves her point by offering some examples of novels

\footnotetext{
all dealing in whole or in part with modern Ireland in its various manifestations pre-Celtic Tiger, Celtic Tiger, post-Celtic Tiger: Nuala O'Faolain, Almost There; Mary Rose Callaghan, Billy Come Home; Lia Mills, Nothing Simple; Catherine Dunne, Set In Stone; Jennifer Johnston, Truth or Fiction; Claire Kilroy, Only the Names Have Been Changed [sic]. Several of my books, which modesty prevents me from naming, could be added to the list (1).
}

It cannot be denied that outstanding contemporary Irish authors continue to successfully delve into the past, as in the case of Joseph O'Connor (Star of the Sea, 2002; Redemption Falls, 2007), Sebastian Barry (Annie Dunne, 2002; A Long Long Way, 2005; The Secret Scripture, 2008; On Canaan's Side, 2011), Colm Tóibín (Brooklyn, 2009; Nora Webster, 2014), Mary Costello (Academy Street, 2014), Lia Mills (Fallen, 2014), Evelyn Conlon (Not the Same Sky, 2015), and Nuala O'Connor (Miss Emily, 2015), to name but some examples of highly acclaimed Irish authors and novels. These works have shared the publishing marketplace with other fictions that deploy the changing socio-cultural circumstances of contemporary Ireland, such as Mary Rose Callaghan's The Visitors' Book (2001), Elizabeth Wassell's The Things He Loves (2001) and Sustenance (2011), Anne Haverty's The Free and Easy (2006), Eillís Ní Dhuibhne's Fox, Swallow, Scarecrow (2007), Chris Binchy's Open-Handed (2008), Peter Cunningham's Capital Sins (2010), Hugo Hamilton's Hand in the Fire (2010), Claire Kilroy's The Devil I Know (2012) Colm Keena's Bishop's Move (2013), Donal Ryan's The Spinning Heart (2012) and The Thing about December (2013), or Paul Murray's The Mark and the Void (2015). Therefore, we cannot agree with Maher and O'Brien when they maintain that there is no serious "fictional representation of the 1990s and beyond, apart from some references in the genres of crime fiction and chick lit" (2014: 6). Furthermore, it has been demonstrated that Irish women writers such as Mary Rose Callaghan, Elizabeth Wassell, Anne Haverty and Eillís Ní Dhuibhne wrote fictions in which they denounced the follies of Celtic Tiger Ireland and even anticipated the social, cultural and economic dangers of a rapidly changing society before the official financial collapse of the island in 2008 (Estévez-Saá 2010; 2013). In this sense, Patricia Coughlan (2004) and Susan Cahill (2012) have shrewdly argued that it can be noticed how current criticism tends to obviate Irish women writers' engagement with social changes in contemporary Ireland, a tendency I would relate to the failure of contemporary criticism to fully and seriously 
acknowledge the excellence of women's contribution, in the past as well as in the present, to the history of Irish literature. Consequently, with the exception of the fortunate recent contributions by Derek Hand (2011), Susan Cahill (2012) and Heather Ingman (2013), little has been said about Irish women writers' brilliant additions to the undeniably excellent recent history of Irish literature. Furthermore, even when a few critical voices, such as those previously mentioned, have deployed Irish women writers' engagement with the most salient concerns of their society and have acknowledged their deep dissection of the changes that have been taking place in the island, these authors' technical and aesthetic genius has been frequently ignored.

I propose to study Anne Enright's recently published novel, The Green Road (2015) in the previously delineated critical context that distances those scholars who have denounced the Irish writers' penchant for the past, from other academics focused on vindicating the existence of fictions that have dissected the present circumstances of the island. I also intend to analyse The Green Road as a further example of Irish women writers' outstanding contribution to the topic, without obviating the writer's skilful engagement with formal and aesthetic choices.

Anne Enright is undoubtedly one of the most important figures in the contemporary literary panorama of Ireland. She has written novels, collections of short stories and essays, her 2007 novel The Gathering being her most outstanding contribution till the publication last year of The Green Road. Her artistry has won her the inaugurate Laureate for Irish fiction by the Irish Arts Council, certainly an unprecedented recognition for a woman and a writer of fiction. Anne Enright has definitively proven with her last novel why she is entitled to such a distinction. In The Green Road Enright skilfully combines the Irish writer's penchant for revisiting the past of the country with an undeniable interest in the dissection of the contemporary socio-cultural circumstances of the island. The novel is both thematically and aesthetically speaking a tour de force in an already outstanding literary trajectory.

The Green Road is divided into two main parts.
The first part of the novel, typographically marked as "Part One. LEAVING", which amounts to half of the novel, begins in 1980 when the Madigan family (Pat and his wife Rosaleen, together with their four children Constance, Emmet, Dan and Hanna) still lived in Ardeevin, County Clare, and finishes in 2005 when the matriarch, now a widow, is the only member of the family who remains at home, after each of her four children has moved to different places. The different sections of this first part are focused on or filtered through one of these children. The second part of the novel is entitled "Part Two. COMING HOME" and takes place in 2005, when the children return home for the Christmas celebrations, summoned by their mother, who intends to sell their home.

Anne Enright has focused, again, on an Irish family, as she had previously done in novels such as The Wig My Father Wore (1995), What Are You Like (2000), The Gathering (2007) and The Forgotten Waltz (2011), as well as in many of her short stories. In an interview that took place in 2008 she acknowledged her interest in the family as a structure that, despite not being "the most glorious institution" has "social benefits" (Randolph 2010: 8) that the writer did not specify. More interestingly, and precisely on the occasion of the publication of The Green Road, she has referred to the structural purpose that the family unit serves in her fiction: "People say I write about the family all the time, but in fact I just put people into that shape, or use that shape to write about deeper truths. I was more interested in separation and connection, disconnection and love" (Clark 2015: 1). The central motif of the family is certainly used so as to illustrate the complexity of the most varied human relationships that include marriage, widowhood, motherhood, sexuality, and ageing. Furthermore, since it is the story of an Irish family from the 1980s till 2005, the experience of emigration and of the returning of their members is adroitly employed by Enright to transcend the local and to cover global issues such as diseases and illness (cancer, AIDS, malaria), and to explore transcultural exchanges in Ireland, as well as in America, Canada, and Africa. It is a recurrent feature of Enright's novels that dysfunctional Irish families 
are structurally employed by the author to offer sound reflections on the recent history of Ireland as well as to transcend the local confines of the island and represent Ireland and the Irish in a global context. ${ }^{2}$

The Green Road begins with an account of family life in the small western Irish town of Ardeevine whose landscape is exalted through the eyes of Hanna, the youngest daughter:

This road turned into the green road that went across the Burren, high above the beach at Fanore, and this was the most beautiful road in the world, bar none, her granny said - famed in song and story - the rocks gathering briefly into walls before lapsing back into field, the little stony pastures whose flowers were sweet and rare (15).

Hanna filters the small-scale experience of its inhabitants in the pre-modern West of the country, where the recent visit of the Pope to Ireland ironically offered the Madigan boys the most salient occasion for the discovery of alternative experiences, the girls being compelled to remain at home:

Hanna blamed the Pope. He came to Ireland just after Dan left for college and it was like he flew in specially, because Galway was where the big Youth Mass was held, out on the racecourse at Ballybrit. Hanna went to the Limerick Mass, which was just like standing in a field with your parents for six hours, but her brother Emmet was let go to Galway too, even though he was only fourteen and you were supposed to be sixteen for the Youth Mass. He left in a minibus from the local church. The priest bought a banjo and when Emmet came back he had learned how to smoke. He did not see Dan in the crowd. He saw two people having sex in a sleeping bag, he said, but that was the night before, when they all camped in a field somewhere (8).

With the exception of the Pope's visit, family life is ruled by routine, village gossip-

2. Heidi Hansson has convincingly interpreted Enright's The Wig My Father Wore as a novel that "represents the idea that Ireland is not an island but part of global culture" (2011: 54-5), and Kristin Ewins has related the fate of the family protagonist in The Gathering with Ireland's fragmented national identity and history (2011). Therefore, the writer had already used the unit of the family so as to fictionalise Irish history and to contextualise Ireland in the contemporary global scene. ing, and a veiled obsession with sexual matters only indirectly referred to by adults and children alike. Irish identity in the 1980s is, therefore, represented as intimately linked to place and controlled by the authority of the Church. $^{3}$ These pillars of identity are beautifully symbolized when Hanna remembers that on Palm Sunday "they had bacon and cabbage with white sauce and carrots - green, white and orange, like the Irish flag" (9).

The rest of the first part of the novel is devoted to narrating the experience abroad of the Madigan children. Enright captures with equal brilliance the rural landscape of the west of Ireland that she depicts the AIDS-devastated gay community of New York in the 1990s, or when she enters the world of the NGOs in early twenty-first century Africa. In this sense, and in comparison with some of her previous novels such as The Wig My Father Wore or The Gathering, the writer's transcendence of the local point of departure is even more emphatically stated. When the author represents the Madigans abroad, she convincingly manages to put Ireland and the Irish in a global context, offering, consequently, an instance of how a writer manoeuvres to further the negotiation between the local culture of departure and the world beyond it. After Hanna's rendering of family life in 1980s Ireland, the reader discovers Dan immersed in the sexually promiscuous, AIDSmenaced, gay community of New York in the 1990s, where the young boy discovers a world of new possibilities open to him:

And Dan forgot for a moment that he was a spoilt priest and English literature graduate with plans to go home, after his year abroad, to do a master's in librarianship. He forgot that he was a shoe salesman, or a barman, or even an immigrant. For a moment Dan was an open space, surrounded by a different future to the one he had brought in through the door (60-1).

The rendering of AIDS-stricken New York is immediately followed by the story of Constance

3. Significantly enough, the nation and the Catholic Church had been traditional cornerstones of Irish identity which crumbled during the Celtic Tiger years, as argued by Gerry Smith in "Irish National Identity after the Celtic Tiger” (2012). 
Madigan, the eldest daughter, living in a now prosperous County Limerick in 1997. Enright not only avoids abandoning the fictional account of the recent history of Ireland, but she also skilfully contrives to place a transnational and transcultural context side by side. The material and social excesses of Celtic Tiger Ireland acquire an international dimension when contextualized in the broader frame offered by affluent, artistic and promiscuous New York.

Anne Enright pays due attention to each of the male and female protagonists, and Dan and Emmet, the Madigan boys, are as carefully presented as their sisters Constance and Hanna. In this sense, this novel confirms the evolution of an author who, despite the undeniable precedent of well-delineated male characters such as Berts in What are You Like, had previously acknowledged that "writing men is the really big problem. I can't write men" (qtd. in Randolph 2010: 11). On this occasion, the author grants male characters more narrative space when compared with previous novels such as The Wig My Father Wore or The Gathering, whose narrators were the female protagonists. Nevertheless, if there is an omnipresent figure in The Green Road, it is that of their mother, Rosaleen, who is constantly being evoked by her children and whose own voice we hear at the end of the first part and in several moments throughout the second part of the novel. Enright has frequently referred to the importance she gives to mothers in her fiction. Already, in 2003, when she was writing The Gathering, she mentioned her concern with a topic that, in her opinion, had been silenced, especially, by male writers:

I am very much interested in the iconized mother figure in Irish literature, because the men can't actually write them. They are very often dead, or left out of the narrative. The mother gets half a sentence and there is an awful lot about fathers. And so in the next book, I split that big iconic mother presence, which for the small children is so large and so unfeasible (qtd. in Moloney and Thompson 2003: 61).

Thus, she announced that, in what was going to be her next book at that moment, The Gathering, "the mother finally speaks in it, as the nearly last thing, and so another woman's story is finally uncovered" (64). The importance of the mother figure in The Green Road is even greater than in Enright's previous novel, where the mother's and especially the grandmother's stories were already heard although through the voice of the daughter, Veronica. The very name of the protagonist, Rosaleen, with its nationalist overtones, ${ }^{4}$ conveys the writer's playful revision and reconceptualisation of colonial and post-colonial idealisation, iconisation and allegorisation of Ireland (Nash 1997: 111-6). Therefore, rather than an idealised Irish mother figure - passive, asexual, domestic, dependent -, we discover a character who defied class and conventions when she married poor Pat Madigan only three months after her father's death, who recalls her satisfactory sexual life with her dead husband, and who is still in her late seventies aware of her body. Furthermore, her reluctance to remain in the domestic sphere is emphasised by the constant allusions to her driving and walking alone, despite her old age, and mostly by her desire to sell a house in which she no longer feels at ease. ${ }^{5}$ Rosaleen is a complex character who also gives vent to the physical and psychological pains that affect her. Prone to tantrums and histrionics, as her youngest

4. James Clarence Mangan's patriotic poem is not only evoked by the protagonist's name but even melancholically quoted by Rosaleen (160-1). In an interview that took place in 2009, Enright acknowledged that she was trying to pull down certain ideas of Irish womanhood and she even announced that, someday, she would call a book "It's not the Rose of Tralee" (Bracken and Cahill 2011: 21). Even though she seems to have opted for a different title, The Green Road certainly plays with and subverts conventional ideas of Irish womanhood.

5. Even though female subversion is a constant in Enright's fiction, she has certainly gone a step further by offering now a sound reflection about an ageing woman and, even though it is not the purpose of the present analysis, it is worth considering the character of Rosaleen as Enright's fictional contribution to women writers' recent interest in offering stories of female ageing that has been documented and studied by, among others, Zoe Brennan (The Older Woman in Recent Fiction), Kathleen Woodward (Figuring Age: Women, Bodies, Generations), or Margaret Cruikshank (Learning to be Old: Gender, Culture and Aging). 
daughter recalls at the beginning of the novel, she laments her children's having abandoned her and her consequent loneliness, as well as the inevitable passing of time and the drawbacks of ageing that she intends to resist:

She walked. Every day she drove out in her little Citroën and she walked. She was the old woman of the roads. But she had legs like Arkle, her husband used to say, by which he meant she was a thoroughbred. Rosaleen recognized, in her reflection, the good bones of her youth. She never lost it. From a distance, if you keep the hump out of your back, you might be any age at all (151).

However, Rosaleen is not the only mother figure in The Green Road. Her daughters Constance and Hannah are also characterised as mothers, and their experiences of motherhood are equally narrated in highly ambivalent terms. Rosaleen, Constance and Hanna feel blessed as well as trapped in their condition as mothers, and the three of them are similarly attached to and isolated from their siblings. Rosaleen, after a life dedicated to raising her children, resents the fact that they abandoned her (154) and consider her the source of all their frustrations, because "that is what your babies do, when they grow. They turn around and say it is all your fault" (152); Constance is similarly distanced from her siblings, "Constance had two sons who told her nothing and a husband who told her nothing and a father who told her nothing and then died" (91); Hanna is the one who most dramatically expresses the antagonism between the mother and the child, when she refers to her baby boy as "A little opposite thing, that is what came out of her. A fight they wrapped in a cloth" (183).

It is particularly interesting how Enright not only gives voice to different mother figures but also vindicates and emphasises the bodies of these maternal characters, bodies that had been traditionally and conventionally confiscated in fiction as Hélène Cixous regretted in her seminal essay "The Laugh of the Medusa" (1976). Thus, the bodies of Rosaleen, Constance and Hannaare dealt with in minute detail. Rosaleen's nostalgic remembrance of past times includes allusions to her legs, reminiscences of her sexual joys in the company of her husband, and, inevitably, references to her decaying body. More importantly, in the cases of Constance and Hanna, the reader discovers the scars left by excesses in their way of living as well as by physical and psychological illnesses. Constance's body has been altered after having given birth to three children, also because of the impact of the consumerism in which she is immersed and is, mostly, menaced by cancer:

Constance used to be pleased with the body that had given her so many surprises, over the years. There were evenings she lay on the sofa with one child paddling her stomach, another pushing, in a tranced sort of way against the fatty side of her chest. Shauna, her youngest, like to sit on the floor and pluck at her calf, making it wobble from side to side. And, 'No! Not the belly button!'Their little fingers pouncing, Constance shrieking and wriggling away. Fun for all the family, she thought, her body was a fabulous object, even Dessie her husband seemed to relish it. But Constance was fed up with herself. And fat, she knew, was a toxic thing (74).

Hanna, the most beautiful of the Madigan children, suffers a chronic depression probably due to having recently experienced maternity but also because of her professional failure in her career as an actress - that compels her to drinking and self-laceration.

We have already mentioned that despite Enright's acknowledged preference for female characters, in The Green Road she has more than satisfactorily managed to deploy the figures of the Madigan boys, Dan and Emmet. Therefore, it is particularly interesting how the author accounts for Dan's experience abroad, for his professional opportunities and sexual choices. Mysterious and beautiful Dan "kept his eyes open" (61), moved into the fine art scene and, allied by his good looks, "noticed people's desire" (61) and fully explored his sexuality. It is, therefore, not surprising that, when summoned by her mother, this ironic "Danny Boy" $(62)^{6}$ is initially reticent and

6. It would not be difficult to notice in the names chosen for all of the members of the Madigan family (Pat, Rosaleen, Emmet, Constance, Dan and Hanna) nationalist overtones with which, more or less consciously, Anne Enright could be ironically playing. 
afraid of going back to his native Ireland: " $[\mathrm{H}]$ he might get stuck in Ireland, somehow, he would get trapped in 1983, with a white sliced pan on the table and the Eurovision Song Contest on TV" (177).

Emmet's portrait is equally fascinating and mysterious. We know that he suffered from depression, almost a recurrent ailment among the Madigans and in Enright's fiction - Hanna acknowledges that hers is not simply a postnatal depression, "No, I've always had it", "I had it pre-natally. I think I had it in the womb" (187); and Constance is on the anti-depressant Serotax since the death of her father (94). As happens with the Madigan girls and with Dan, Emmet's psychological and physical features are carefully delineated: "Emmet, too, was drawn to suffering - it was, after all, his job" (106); "Emmet was so long in the heat, the exposed skin was a different age to the hidden parts of him; he had sixty-year-old knees and the belly of a young man" (109). Consequently, Enright avoids and transcends stereotypes in her fiction: men's and women's bodies do equally matter, and contemporary psychological disorders - lack of communication, isolation, depression, frustration - affect the young and the old, mothers and their siblings, in Ireland and elsewhere.

Furthermore, Dan and Emmet's experiences of emigration are used by Enright not only to transcend local Ireland but also to exemplify alternative views on the role of Irish emigrants abroad. Therefore, far from the traditional representation of the hardships of Irish émigrés in their countries of destination, we discover Dan successfully integrated in the artistic gay atmosphere of New York and Toronto, uninhibitedly exploring and living his sexuality; as well as Emmet actively participating in international welfare campaigns. And like the neat presentation of the New York gay community of the 1990s, in Emmet's portrait, the reader of The Green Road also witnesses the adverse circumstances of third world Africa, as well as the difficult condition of those working in international aid:

People always wanted to know about the Sudan. Two thousand people sucking water from the same patch of mud. Thirty water pumps stuck at the airport, and every piece of paper shuffled and lost by the bastards in Khartoum (115).
And the street was a medical textbook, suddenly. People with bits missing. The bulge of tumour about to split the skin. The village idiot was a paranoid schizophrenic. A man with glaucous eyes was sweating out a fever in a beautiful carved chair, his head tipped back against the wall (118).

In the second part of the novel, the homecoming of the two brothers is used ironically to contrast the Ireland they left as young boys, and that they are afraid to meet again, with the new sociocultural circumstances of the island. Thus, if Dan fears being trapped in his native country, Emmet does not recognize a place that has utterly changed:

Emmet looked out the window at the identical house on the other side of the road, alive with fairy lights. Since the money came in, Ireland depressed Emmet in a whole new way. The house prices depressed him. And the handbag thing, the latte thing, the Aren't We All Brilliant thing, they all depressed him too (206).

The atmosphere of Celtic Tiger Ireland is best captured on the occasion of the Christmas celebration: "It was 10 a.m. on Christmas Eve and the supermarket was like the Apocalypse, people grabbing without looking, and things fallen in the aisles" (228); and Enright is particularly sharp as well as funny with the minute description she offers of Constance's compulsive consumerism with the endless list of needless items she buys and the amount of money she wastes: "The bill came to four hundred and ten euros, a new record. She thought she should keep the receipt for posterity. Dessie would be almost proud" (230).

Enright delves into the most varied aspects of contemporary Ireland and transcultural relationships are also succinctly and adeptly deployed. Therefore, Dan's and Emmet's successful involvement in their respective international experiences and affairs are shrewdly contrasted with the pettiness of Irish attitudes towards foreigners. Constance's affair with a Malaysian medical student (85), or her Mongolian cleaner (228) hint at an intercultural society that, nevertheless, is still unable to fully integrate its new citizens, as is shown when Emmet realizes that he cannot invite his Kenyan friend, Denholm, to share his family's Christmas table: 
After all the hospitality he himself had been offered, in so many towns. Why did he not invite him home for his dinner? He just couldn't. It was not a question of colour (though it was also a question of colour), even Saar was out of the question - Saar with her Dutch domestic virtues, [...] Christmas dinner for Emmet's family, was thicker than Kenyan blood soup, so none of the people that Emmet liked best could be there, nor even the people he might enjoy. The only route to the Madigans' Christmas table was through some previously accredited womb. Married. Blessed.

I am sorry. I can not invite you home for Christmas because I am Irish and my family is mad.

Hanna wasn't even bringing the father of her child.

High standards at the Madigans' dining room table. Keep 'em high (212).

Enright's revision of more than twenty years in the recent history of Ireland vindicates the need to look at the past so as to discover the shortcomings of Ireland's present, as the only way of projecting a better future. Not in vain, Rosaleen, the most clearly self-absorbed character in the novel, finally acknowledges "I have paid too little attention", "I think that's the problem. I should have paid more attention to things" (310). Despite the open ending of the novel, Rosaleen seems to experience a kind of epiphany.

R. F. Foster has concluded his shrewd analysis of the years of change in the isle, in Luck and the Irish. A Brief History of Change, 1970-2000, with a chapter significantly entitled "The Strange Death of Romantic Ireland", where he convincingly vindicates the need to reflect on the past so as to live in the present and understand the future: "The pragmatic new Ireland has shown a similar tendency, like America, to live aggressively in the present. As Ahern pointed out, this is better than living in the past. But understanding the future requires an expanded sense of what has just happened, and a map of the landscape receding so bewilderingly behind us" (2007: 188-9, emphasis mine). Anne Enright seems to be of a similar opinion since The Green Road should be considered as a narrative that both thematically and aesthetically establishes a dialogue with the past, engages in the present, and signals the future of Ireland and of Irish literature. Without nostalgically looking back to Ireland's past, she has certainly offered a compelling rendering of the last two decades of the twentieth century. Furthermore, she has denounced through her characters not only the need of "paying attention to things", as Rosaleen states in the very last lines of the novel, but also of recuperating what Dan describes, in very similar terms to Foster's, as "A map of things he had known and lost" (203). Attention and knowledge are presented in the novel as indispensable attitudes in order to, at least, discern the circumstances of contemporary life, which should also guide the characters to detect if not amend the dangers of silence and wordlessness. When Hanna and Emmet come back home and are thinking about their mother, it is stated that "It still got to them. Rosaleen never said it to your face, whatever it was. She moved instead around and behind their children". Rosaleen's grown up children seem to finally recognize what has distanced them from their mother and the germ of their suffering in "All things that were unsayable: failure, money, sex, drink" (224).

The study of Enright's evocation of the past and contribution to the dissection of the present in The Green Road could be extended to the formal and aesthetic dimension of her novel. From the perspective of form, The Green Road is probably Enright's most interesting experiment with the genre of the novel to date. We have already mentioned the two-part general structure and the different sections of diverse length in which each of the two parts are divided, as well as the significance of their being named "Part One. LEAVING" and "Part Two. COMING HOME". It is also particularly interesting that the author has provided titles for all these sections or fragments, since they convey the importance of individuals, places and dates in the first part of the novel ("Hanna, Ardeevin, Co. Clare, 1980"; "Dan, New York, 1991"; "Emmet, Ségou, Mali, 2002"; "Rosaleen, Ardeevin, 2005"). Furthermore, the epigraphs in the second part show how the combination of the concrete and the abstract, the local and the universal, the traditional and the contemporary ("Property", "Paying Attention", "Shannon Airport", "A Face in the Crowd", "The Hungry Grass", "The Eyes of the Buddha"), are fused in a narrative that emulates 
a container that carries the most diverse experiences and preoccupations of an Irish family that stands for the difficulty of affective relationships (lack of communication, misunderstandings, loneliness, depression) in contemporary western societies.

The first part includes different sections devoted to each of the protagonists that stand on their own, almost a collection of short stories, frequently narrated in a free indirect style close to interior monologue. The fragmentation of the first part is best suited to evoke the compartmentalised lives of the Madigan children and the almost total lack of communication among them. The sections in part two are shorter and oriented towards the coming home and reuniting of the Madigans. Therefore, the tempo of the narrative is quicker in a second part that reproduces the movements of the protagonists towards the final reunion. Furthermore, the more fragmented, less structured and stylistically more diverse second part of the novel deploys the chaotic and conflictive nature of the family encounter, as well as the unstable and fragile lives of their protagonists, and the difficulties and problems of communication among them.

Enright has expertly adapted the form of the novel to the stories she wanted to tell and, in particular, to the circumstances of their protagonists. She has also offered a further example of the particular situation of the novel in Irish literature, a genre that, as Derek Hand has argued, "has been and continues to be caught between the desire to be exceptional and the endless possibilities of ordinary life" (2011: 13). Previously, Terry Eagleton had stated in his influential Heathcliff and the Great Hunger: Essays in Irish Culture "That the novel in Ireland never flourished as vigorously as its English counterpart is surely no mystery" (1995: 145). Eagleton alluded more specifically to the case of the realist novel and explained it as follows: "literary realism requires certain cultural preconditions, few of which were available in Ireland. The realist novel is the form par excellence of settlement and stability, gathering individual lives into an integrated whole; and social conditions in Ireland hardly lent themselves to any such sanguine reconciliation" (1995: 147). Therefore, there are critics who have dated the definitive consolidation of the novel in Ireland in the late twentieth century. R. F. Foster, in his book Luck and the Irish. A Brief History of Change, 1970-2000, in a chapter significantly entitled "How the Short Stories Became Novels", states that it was in the seventies when "the 'classic' Irish short story, revolving around an emblematic episode or epiphany, was replaced by the expansive, teeming world of the novel" (2007: 147). Similarly and more recently, George O'Brien in The Irish Novel: 1960-2010 affirms that "If there is one literary landmark more prominent than another in Irish culture over the past fifty years, it is the growth and development of the novel" (2013: ix).

The previously mentioned are representative examples of critics who have recently assessed the status of the novel in Irish literature. The overall impression is that it was not a literary genre favoured by Irish writers until, at least, well into the second half of the twentieth century, despite brilliant contributions to the genre by authors such as James Joyce, Samuel Beckett, or Flann O'Brien, among many others. This interpretation of the novel in Irish literary history, is probably the result of some critics' consideration of the genre of the novel in a restricted sense, as a long straight-forward narrative in prose, in a predominantly realist mode. It should rather be argued that the novel was from the beginning something different in Ireland and that definitions of the genre in such restrictive terms do not work in the case of Irish literature. This is the critical stance maintained by Derek Hand, in his recent and comprehensive A History of the Irish Novel, where he has also referred to "the major misconception that there is no such thing as an Irish novel. Or if there is, it is but a pale imitation of what a real novel ought to be" (2011: 2). Hand judiciously argues that perhaps "much of this type of critique is a dangerously simple misreading of the novel form" (2011: 3) that looked narrowly "to the realisms of the nineteenth century novel as the ideal to be copied, forgetting that the form's original power emanated from the vulgar chaos of the picaresque and the whimsy of romance" (2011: 4). Derek Hand's broadest conception of the novel is worth taking into account since, as he maintains, the novel is a literary genre "awash with contradictions and, perhaps, beyond any 
final definition as it wilfully plunders various forms and genres for its own ends" (2011: 2). What is more, according to Hand "it could be argued that it is these contradictions which energise the novel -its rage for order straining against a shapeless form endlessly and necessarily redefining itself, its desire to map the emerging middle-class individual contrasting dynamically with novel's ability to focus on society" (2011: 2).

Formally speaking, I would align Enright's The Green Road with this ambiguous status and history of the novel in her native country since she is certainly proposing a further structurally and aesthetically sophisticated use of a genre that she is adapting for her own purposes, as Lawrence Sterne, Maria Edgeworth, or James Joyce had done before her; and Enright is certainly exemplifying how, in Irish literature, "The novel form, oscillating between containment and chaos, between the simplicity of narrative progress and the complexity of expression, seems best suited to capturing the energies of an Irish culture which also moves between the poles of stability and social coherence and the ever-present realities of division and conflict" (Hand 2011: 9). Although chronologically ordered, The Green Road presents a highly fragmented structure, as well as the combination of a profusion of different styles: realist episodes are exceeded by almost naturalistic accounts, such as Constance's description of her experience during her mammography, Emmet's descript- tion of different illnesses in Sudan and Mali, or the account of Hanna's bleeding after falling and cutting herself with a bottle in her kitchen during one of her bouts of drunkenness. Enright has not even fully abandoned the magic realist aesthetics of previous novels such as The Wig My Father Wore, The Pleasures of Eliza Lynch or The Gathering, as in the episode when Rosaleen imaginatively encounters her dead husband.

Enright's work has been catalogued as postmodernist "in its emphasis on fragmentation, metafiction, parody, parataxis, linguistic play and privileging of performative and 'atomised' identities" (Bracken and Cahill 2011: 9). However, the author herself has specified the type of postmodern agenda she subscribes to: "whatever postmodern impulse I have, it is an attempt to be more honest and not less. It's not an attempt to be clever, it's an attempt to be honest" (Bracken and Cahill 2011: 18). This honesty, as deployed in The Green Road, implies adapting the form of the novel to cover the past and the present, the local and the global, unity and fragmentation, success and failure; and she has offered, as acknowledged by one of the protagonists, "A map of things known and lost" (203), that inevitably hints at, although cannot fully and honestly express, "All the things that were unsayable" (224) about the recent past and about the present of Ireland and of the Irish, as well as about the present circumstances of our contemporary society.

\section{Works Cited}

Bracken, Claire and Susan Cahill (eds.). 2011. Anne Enright. Dublin: Irish Academic Press.

Brennan, Zoe. 2005. The Older Woman in Recent Fiction. Jefferson, North Carolina: McFarland \& Company, Inc.

Cahill, Susan. 2012. Irish Literature in the Celtic Tiger Years, 1990-2008. Gender, Bodies, Memory. New York \& London: Bloomsbury.

Cixous, Hélène. 1976. "The Laugh of the Medusa”. Signs 1.4 (Summer): 875-93.

Clark, Alex. 2015. "Anne Enright". The Guardian. Sunday 9 August. http://www.theguardian.com/books/2015/aug/09/anne-enright-ireland-is-my-home-but-i-feel-i-have-beentrying-to-leave-all-my-life [retrieved: 19/11/2015]

Coughlan, Patricia. 2004. "Irish Literature and Feminism in Postmodernity". Hungarian Journal of English and American Studies10. 1-2: 175-202.

Cruiskshank, Margaret. 2013. Learning to Be Old: Gender, Culture, and Aging. New York: Rowman \& Littlefield Publishers.

Eagleton, Terry. 1995. Heathcliff and The Great Hunger: Essays in Irish Culture. London and New York: Verso. 
Enright, Anne. 2015. The Green Road. London: Jonathan Cape.

Estévez-Saá, Margarita. 2010. "Antidotes to Celtic Tiger Ireland in Contemporary Irish Fiction: Anne Haverty'sThe Free and the Easy and Éillís Ní Dhuibne'sFox, Swallow, Scarecrow”. 'In the Wake of the Tiger.' Irish Studies in the Twentieth-First Century, David Clark and Rubén JarazoÁlvarez (eds.). A Coruña: Netbiblo. 199-210.

2013. "Immigration in Celtic Tiger and post-Celtic Tiger Novels". Literary Visions of Multicultural Ireland. The Immigrant in Contemporary Irish Literature”, Pilar Villar-Argáiz (ed.). Manchester: Manchester University Press. 79-92.

Ewins, Kristin. 2011. “History is Only Biological': History, Bodies and National Identity in The Gathering and 'Switzerland"'. Irish Writers in Their Time: Anne Enright, Claire Bracken and Susan Cahill (eds.). Dublin: Irish Academic Press. 127-44.

Fogarty, Anne. 2003. "Preface". Midwife to the Fairies: New and Selected Stories. Éilís Ní Dhuibhne. Cork: Attic Press. ix-xv.

Foster, R. F. 2007. Luck and the Irish. A Brief History of Change, 1970-2000. London: Penguin Books.

Gough, Julian. 2010. "The State of Irish Literature" Julian Gough Journal. http://www.juliangough. com/journal/2010/2/10/the-state-of-irish-literature-2010.html [retrieved: 29/04/2015]

Hand, Derek. 2011. A History of the Irish Novel. Cambridge: Cambridge University Press.

Hansson, Heidi. 2011. "Beyond Local Ireland in The Wig My Father Wore”. Irish Writers in Their Time: Anne Enright, Claire Bracken and Susan Cahill (eds.). Dublin: Irish Academic Press. 51-66.

Ingman, Heather. 2013. "The New Woman in the Celtic Tiger Years and After", Irish Women's Fiction: From Edgeworth to Enright. Co. Kildare, Ireland: Irish Academic Press. 237-58.

Kiberd, Declan. 2005. The Irish Writer and the World. Cambridge: Cambridge University Press.

Maher, Eamon and Eugene O'Brien (eds.). 2014. From Prosperity to Austerity. A Socio-Cultural Critique of The Celtic Tiger and Its Aftermath. Manchester: Manchester University Press.

Moloney, Caitriona and Helen Thompson. 2003. Irish Women Writers Speak Out: Voices from the Field. New York: Syracuse University Press.

Nash, Catherine. 1997. "Embodied Irishness: Gender, Sexuality and Irish Identities". In Search of Ireland: A Cultural Geography, Brian Graham (ed.). London: Routledge. 108-27.

Ní Dhuibhne, Eilís. 2010. “Irish literary writers 'cut off' from current of culture”. The Irish Times. 11 March. http://www.irishtimes.com/opinion/letters/irish-literary-writers-cut-off-from-current-of-culture-1.636167 [retrieved 02/09/2015]

O’Brien, George. 2013. The Irish Novel, 1960-2010. Cork: Cork University Press.

O'Toole, Fintan. 2001. "Writing the boom". The Irish Times.25 January. http://www.irishtimes.com/culture/writing-the-boom-1.273557 [retrieved: 27/04/2015]

2010. "Why Irish writers don't grow out of adolescence". The Irish Times.6 November. http://www.irishtimes.com/culture/books/why-irish-writers-don-t-grow-out-of-adolescence-1.673529 [retrieved 09/11/2015]

Randolph, Jody Allen. 2010. Close to the Next Moment. Interviews from a Changing Ireland.Manchester: Carcanet Press Limited.

Smith, Gerry. 2012. "Irish National Identity after the Celtic Years". EstudiosIrlandeses7: 132-7.

Woodward, Kathleen, ed. 1999. Figuring Age: Women, Bodies, Generations. Bloomington \& Indianapolis: Indiana University Press.

Received 30 November 2015 Last version 1 February 2016

Margarita Estévez-Saá is Senior Lecturer in English Literature at the University of Santiago de Compostela. She edits Papers on Joyce, and her research interests include James Joyce, contemporary Irish literature, critical theory, and feminist criticism. 